\title{
MULTI-CRITERIA DECISION MAKING IN CIVIL ENGINEERING: PART I - A STATE-OF-THE-ART SURVEY
}

\author{
Edmundas Kazimieras ZAVADSKAS ${ }^{a}$, Jurgita ANTUCHEVIČIENÉ a , Oleg KAPLIŃSKI ${ }^{b}$ \\ ${ }^{a}$ Faculty of Civil Engineering, Vilnius Gediminas Technical University, \\ Saulètekio al. 11, 10223, Vilnius, Lithuania \\ ${ }^{b}$ Faculty of Architecture, Poznań University of Technology, Nieszawska 13C, 60-965 Poznań, Poland
}

Received 20 November 2015; accepted 19 December 2015

\begin{abstract}
For several decades, multi-criteria decision-making (MCDM) methods have been in use to address issues particular to design, organisation and management of constructions. This article reviews the history of MCDM methods since their origins to current times. The academic database Thomson Reuters Web of Science Core Collection was used to overview publications that contain keyword "MCDM" and are included in Web of Science Category "Engineering Civil". The analysis of publications was made according to their year, state, journals and used MCDM methods.
\end{abstract}

Keywords: civil engineering, MCDM, MADM, Web of Science.

\section{Introduction}

The design and implementation of an effective life-cycle process of a building require focusing on rationality throughout the entire development since the definition of needs and goals to the very end-of-life stage of the building. There is a number of stakeholder groups concerned with stages of the life-cycle of a building: customers, designers, contractors, producers and suppliers of materials and products, users, managers, selfgovernance institutions, building maintenance and repair organisations, etc. It is already during the design of a building that decision-making must consider the needs and goals of these groups. The life-cycle process of a building must be designed and implemented in view of its stages, possibilities and goals of stakeholder groups, all of which impact on the effectiveness of the life-cycle process of a building, as well as considering the external environment. A variety of factors impacting on the effectiveness of the life-cycle process of a building leads to a relevant question: how to assess decisions of the process from several aspects (Zavadskas et al. 2001)?

Aiming to achieve strategic, economic, social, technical, qualitative or other aims, it is necessary to draw on quantitative and qualitative assessment criteria that describe possibilities and goals particular to stakeholder groups of the life-cycle process of a building, alternative solutions and the existing situation of the external environment. Multiple-criteria analysis methods, which can also be successfully introduced into decision support systems, have to be used to define, reason and achieve these aims (Zavadskas et al. 1998, 1995; Filip et al. 2014).

\section{The development of MCDM methods}

Multiple-criteria decision making (MCDM) has grown as a part of operations research, concerned with designing mathematical and computational tools for supporting the subjective evaluation of performance criteria by decision makers (Mardani et al. 2015).

Corresponding author:

E. K. Zavadskas E-mail: edmundas.zavadskas@vgtu.lt 
MCDM methods cover a wide range of somewhat distinct approaches. MCDM methods can be broadly classified into two categories: discrete MCDM or discrete MADM (Multi-Attribute Decision Making) and continuous MODM (Multi-Objective Decision Making) methods (Fig. 1) (Zavadskas, Turskis 2011).

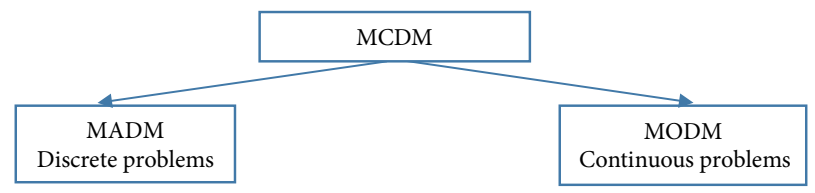

Fig. 1. Broad classification of MCDM methods

MCDM methods were originally created by Franklin (1772), Condorcet (1785), Borda (1785), Cantor (1874), Edgeworth (1881), and Pareto (1896-1897, 1906, 1971). Since 1992, the International Society of Multiple-Criteria Decision Making has been giving out Georg Cantor awards and Edgeworth-Pareto awards.

First axioms essential for the selection of the most valuable alternatives were formulated by Ramsey (1931). In 1944, John von Neumann and Oskar Morgenstern continued Ramsey's work and prepared their monumental masterpiece entitled Theory Games and Economic Behavior (1944). For the contributions to the development of game theory, Nash (1950a, 1950b) received the Nobel Prize in 1994. Next, the Theory of Valuef was developed by Gerard Debreu (1959) who was also awarded the Nobel Prize. Yet another Nobel Prize laureate (1970) Samuelson (1938) announced a very important piece of work. Edwards (1954) published the theory of decision making. The piece of work of Simon (1955), Nobel Prize laureate (1978), played a special role in the most up-to-date MCDM theory. An important role in the development of MCDM was played by efforts of Arrow (1951) and Sen (1970). The authors also became laureates of the Nobel Prize. Luce and Raiffa (1957) introduced the newest decision theory. Frisch (1961) received the Nobel Prize for a relatively little-known publication. A great input into the MCDM theory was made by Fishburn $(1964,1970)$ who publicised two books on issues of the value theory. A significant contribution to the development of the MCDM theory was also made by Roy (1968). Multiple Objective Mathematical programming techniques were created by Dantzig (1948) and Kantorovich (1939), who were also awarded the Nobel Prize. Koopmans (1951) elaborated on Pareto's theory and was also awarded the Nobel Prize in 1975. Other important contributions were made by Gass and Saaty (1955), Zeleny (1974), Charnes et al. (1978).

Zadeh (1965) announced the Fuzzy Sets Theory. This year was the 50th anniversary since the introduction of this theory. To commemorate this date, the journal Technological and Economic Development of Economy, which is jointly published by VGTU and Taylor and Francis, released a special anniversary issue. The introductory article was authored by one of the most renowned scholars of MCDM Herrera-Viedma (2015). Other articles were authored by VGTU researchers Turskis, Antuchevičienè, Banaitis and Banaitienè with co-authors (Razavi Hajiagha et al. 2015; Khandekar et al. 2015; Pourahmad et al. 2015). To commemorate this anniversary, the journal International Journal of Computers Communications \& Control released a thematic issue as well. This special issue had the introduction written by world-renowned scientist Ronald R. Yager (2015). It also contained an article authored by VGTU researchers (Turskis et al. 2015).

MCDM name was first used in an article by Zeleny (1975). Later, this new notion was explained by Zionts (1979).

Especially important results of the MCDM topic were announced in books by Keeney, Raiffa (1976), Zeleny (1982) and Saaty (1980).

Hwang et al. (1979) reviewed MODM methods, and Hwang and Yoon (1981) overviewed MADM methods (SAW, TOPSIS, ELECTRE, LINMAP and the permutation method).

Since 1980, MCDM methods were rapidly developed in various areas. In 1986, Peldschus defended a post-doctoral dissertation on the use of gaming theory to address construction problems.

In 1987, at Moscow Institute of Civil Engineering, Zavadskas defended a post-doctoral dissertation, in which MADM methods were used to deal with Civil Engineering problems (Zavadskas, 1987a). Later, 35 doctoral dissertations were defended under his leadership, all of which focused on the used MCDM methods.

MCDM methods were overviewed in books by Hwang, Lin (1987), Roy (1996), Saaty (1996), Belton, Stewart (2002), Brauers (2004), Figueira et al. (Eds.) (2005), Bouyssou et al. (2006), Kahraman (Ed.) (2008), Miettinen (2009), Hanne (2009), Triantaphyllou (2010), Ehrgott et al. (Eds.) (2010), Zopounidis and Pardalos (Eds.) (2010), Kaliszewski (2010), Pedrycz et al. (2010), Tzeng, Huang (2011), Köksalan et al. 
(2011), Doumpos and Grigoroudis (2013), Ishizaka and Nemery (2013).

Zavadskas (1987b, 1991, 2000) authored books, in which MCDM methods were used to address construction problems. VGTU researchers announced a number of books dedicated to the use of MCDM methods in Civil Engineering: Zavadskas et al. (1994a, 1995, 1998, 2001, 2004a), Peldschus, Zavadskas (1997), Kaklauskas, Zavadskas (2002, 2015) and Zavadskas, Kaklauskas (2007).

The use of MCDM methods is discussed in monographs by Kapliński (1997), Kapliński (Ed.) (2007), Chen and Li (2006), Koo et al. (2009).

The evolution of MCDM in 1975-2015 was discussed in a number of review articles: Wiecek et al. (2008), Zavadskas et al. (2008, 2014), Kapliński (2009a, 2009b), Zavadskas, Turskis (2011), Liou, Tzeng (2012), Tamošaitienė, Kapliński (2013), Liou (2013), Gay, Sinha (2013), Kaplinski et al. (2014a, 2014b), Kabir et al. (2013), Masri (2014), Mardani et al. (2015a, 2015b, 2015c).

Up to 1991, no articles containing examples of the use of MCDM methods in Civil Engineering were referred in ISI Web of Science database. First articles addressing the use of MCDM methods in Civil Engineering were authored by Duckstein et al. (1991), Shafike et al. (1992), Sobanjo et al. (1994), Bose, Chakrabarti (2003). First Lithuanian authors to publish papers in Isi Web of Science data base on this topic were Zavadskas et al. (2003, 2004b).

The development of MCDM methods and their application in Civil Engineering was discussed in many articles (Kapliński 2008a, 2008b; Zavadskas et al. 2008; Kapliński, Tamošaitienė 2010; Kaplinski, Tupenaite 2011; Tamošaitienè, Kapliński 2013; Kaplinski et al. 2014a, 2014b; Jato-Espino et al. 2014; Antucheviciene et al. 2015; Kaplinski, Tamošaitienè 2015).

Since 1986, Leipzig Higher Technical School, Poznan University of Technology and Vilnius Civil Engineering Institute (later renamed into Vilnius Technical University and Vilnius Gediminas Technical University) commenced with biannual colloquiums, which addressed issues related to the development and application of MCDM methods in Civil Engineering (Fiedler et al. 1986; Peldschus 1995; Kapliński et al. 2004; Kaklauskas et al. 2005; Peldschus et al. 2006; Zavadskas 2008; Tamosaitiene et al. 2010; Kapliński 2010; Peldschus 2013). Later, a EURO Working Group on Operational Research in Sustainable Development and Civil Engineering was established. Work by this group is coordinated by researchers of VGTU Department of Construction Technology and Management (Zavadskas, Vilutienè 2013). This Working Group issues an annual newsletter (The Association of... 2015). In 2015, the 15th German-Lithuanian-Polish colloquium (ORSDCE 2015) was organised by this group in Poznan. On the occasion of the event, Elsevier issued a publication Procedia Engineering, Volume 122 (Kaplinski et al. 2015).

\section{Research methodology}

In this paper, the literature related to MCDM has been reviewed comprehensively on the basis of papers referred in Thomson Reuters Web of Science academic database. Following a methodological analysis (Fig. 2) on the entire body of collected publications, a number

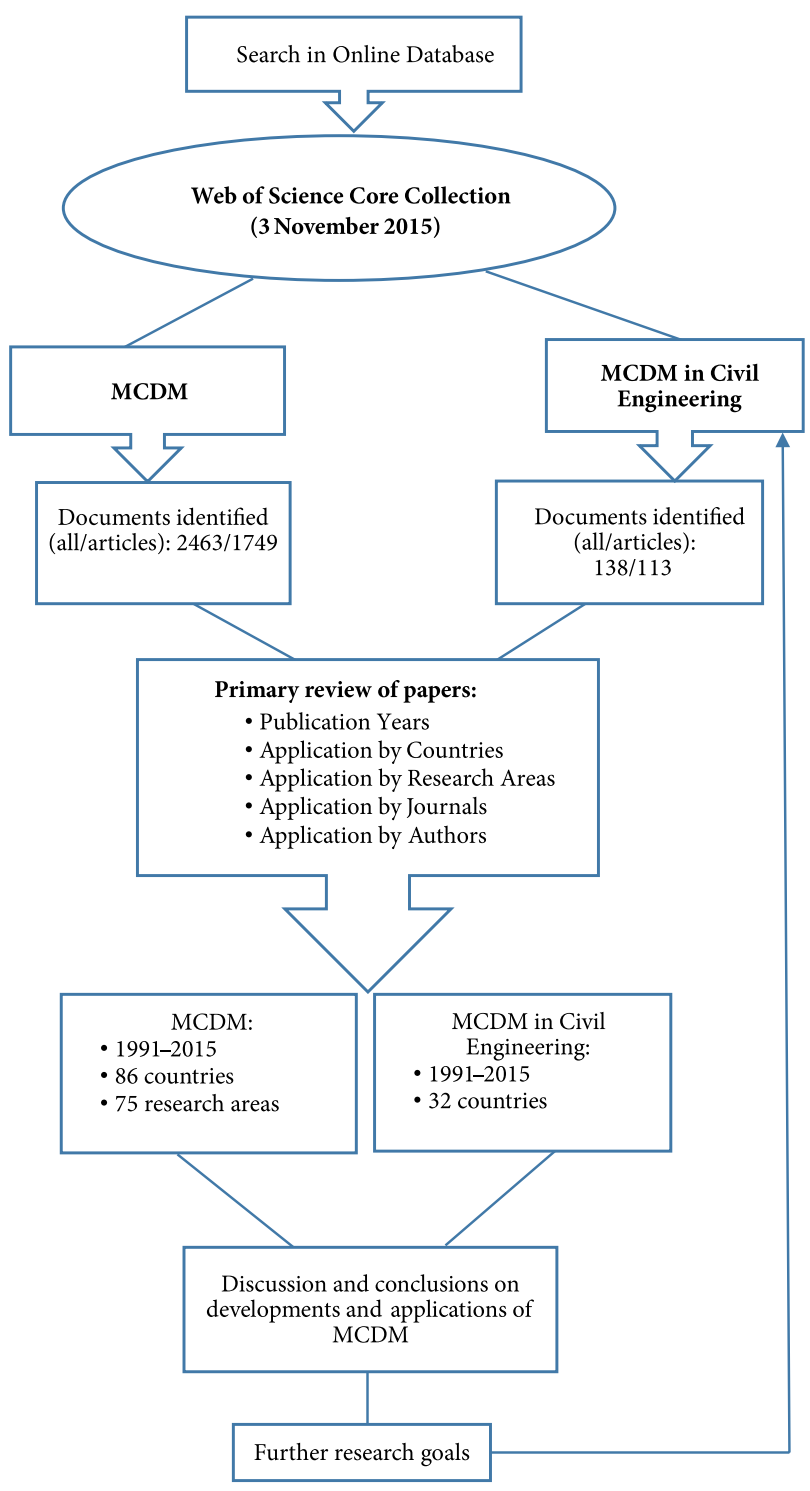

Fig. 2. Summary of the research procedure 
of articles were reviewed from the first international publications in the area up to now (October 2015). The presented research attempts to answer the following questions: (1) How have the papers been distributed by the period of publishing? (2) How have the papers been distributed by a country? (3) In what research areas MCDM has been applied? (4) How have the papers been distributed by authors? (5) How have the papers been distributed by journals?

\section{Number of publications by year}

Web of Science Core Collection contains 2463 referred publications (Figs 3, 4) on the topic of MCDM (3 November 2015), covering all document types, including articles (1749) (Fig. 4) (Table 1).
Table 1. Publications on the topic of MCDM in Web of Science database

\begin{tabular}{|c|c|}
\hline Publications on MCDM methods & Number of publications \\
\hline All & 2463 \\
\hline Articles & 1749 \\
\hline Publications on Engineering Civil & \\
\hline All & 138 \\
\hline Articles & 113 \\
\hline
\end{tabular}

The publications that are dedicated to Civil Engineering with applied MCDM methods are taking the tenth place and amounting to $5.6 \%$ of the total number of publications dedicated to MCDM (i.e., 113 articles) (Fig. 3).

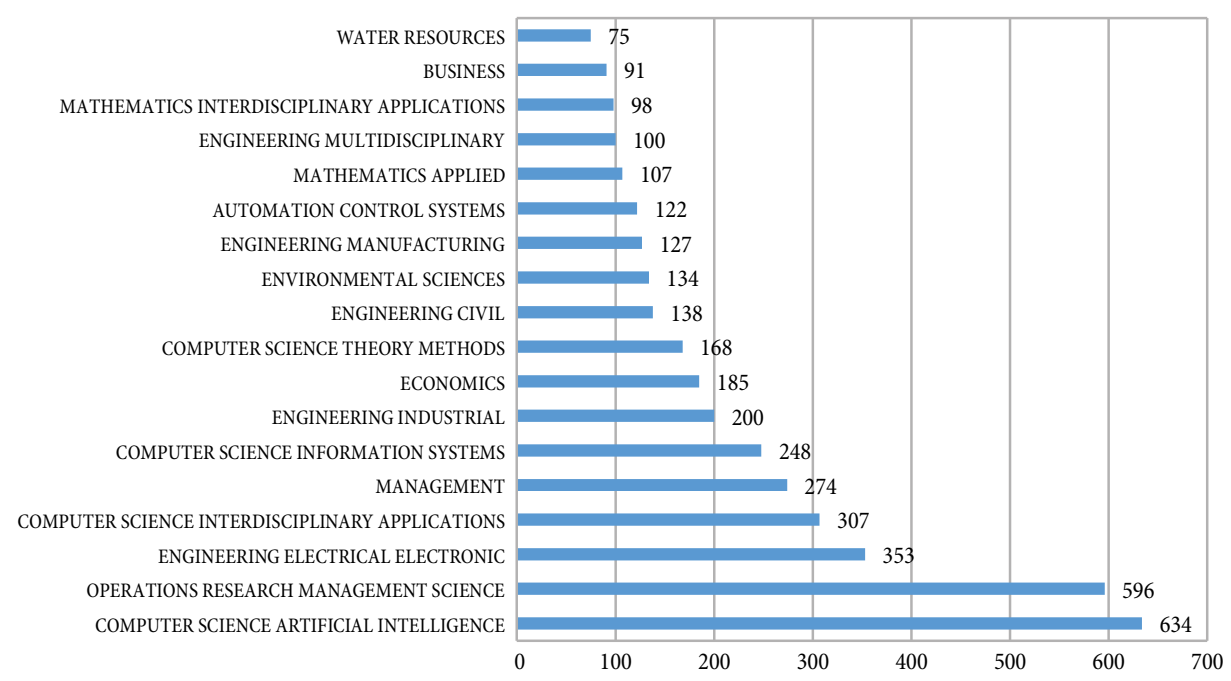

Fig. 3. Web of Science database (total: 2463)

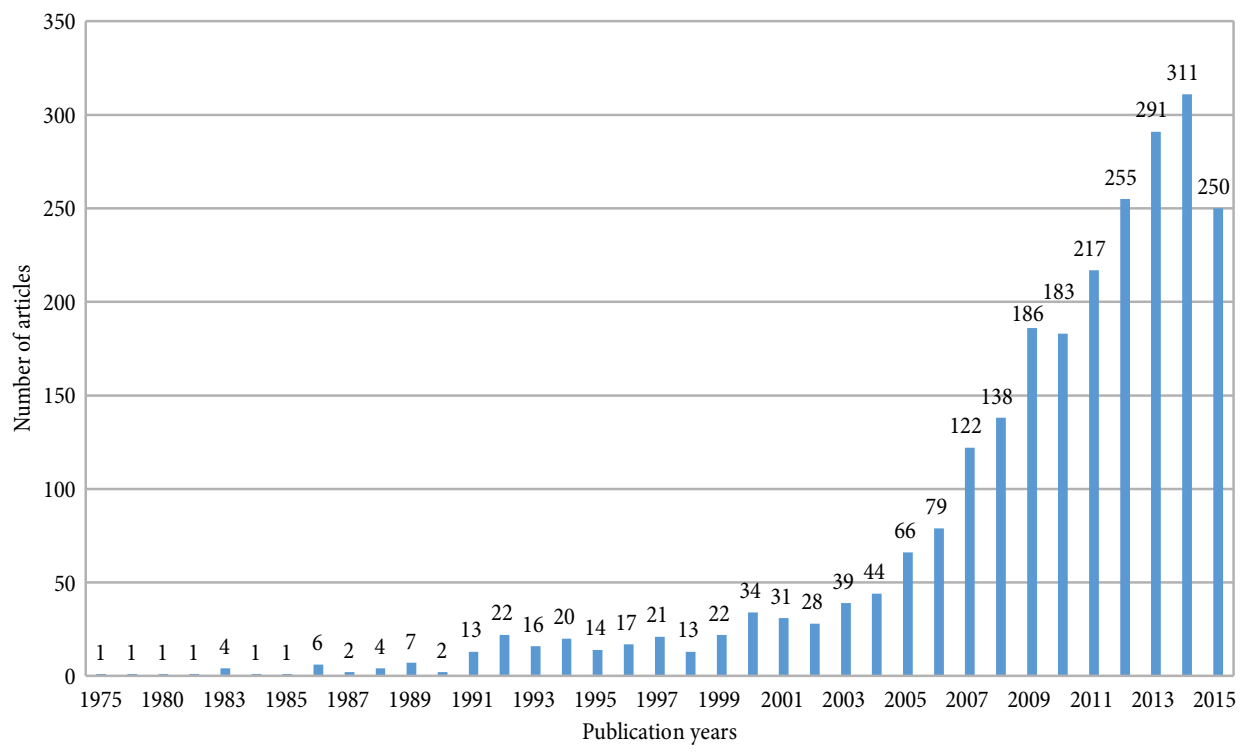

Fig. 4. Number of publications on the MCDM topic (total: 2463) 


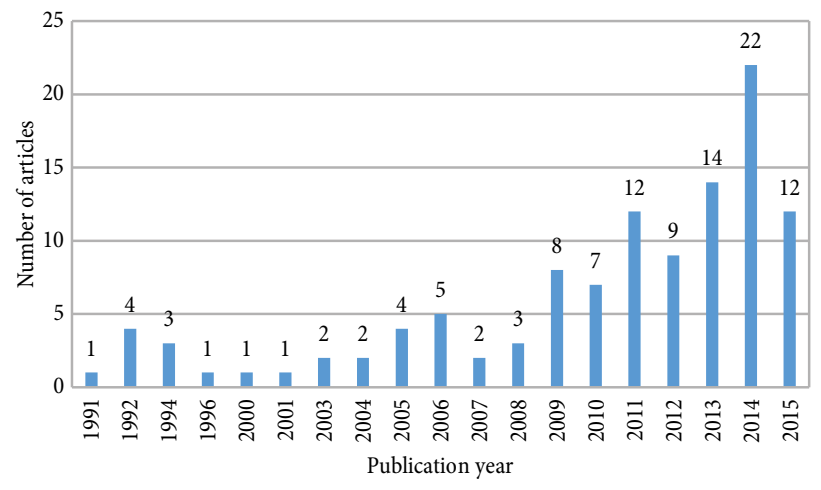

Fig. 5. Number of publications on the category "civil engineering+MCDM" (total: 113)

As depicted in Figure 5, the extent of research in the area has been rapidly increasing during the last ten years. Numbers of publications on MCDM increased from one-to-two papers per year up to 22 journal articles in 2014. As much as 61 per cent of articles on the topic were published during the last five years (2011-2015). Articles published in the last three years (2013-2015), comprise a share of 42 per cent.

\section{Number of publications: by country, author, journal and MCDM methods}

Further, the analysis focused on the use of MCDM by country. Articles were announced by researchers representing thirty countries of the world. Information on the distribution of MCDM papers by country is given in Figure 6, which shows that Lithuanian authors announced 22 articles. This number amounts to about $20 \%$ of the total number of articles, which places Lithuania in the second place following the USA.

Authors listed in Table 2 published their articles on the topic of the MCDM use in Civil Engineering. The table demonstrates that Lithuanian authors are leaders of this particular topic. The top ten has four Lithuanian authors. Articles were announced by 100 authors, and 15 (15\%) of them were Lithuanians.

Table 3 provides information on journals in ISI Web of Science database, which issued publications on the use of MCDM methods in Civil Engineering. In total, articles were announced in 44 journals. The majority of publications - 18 - were announced in Springer Publishing journal Water Resources Management. The second place with 17 publications is occupied by the Journal of Civil Engineering and Management published by VGTU and Taylor \& Francis. Elsevier and Wroclaw University of Technology take the third place

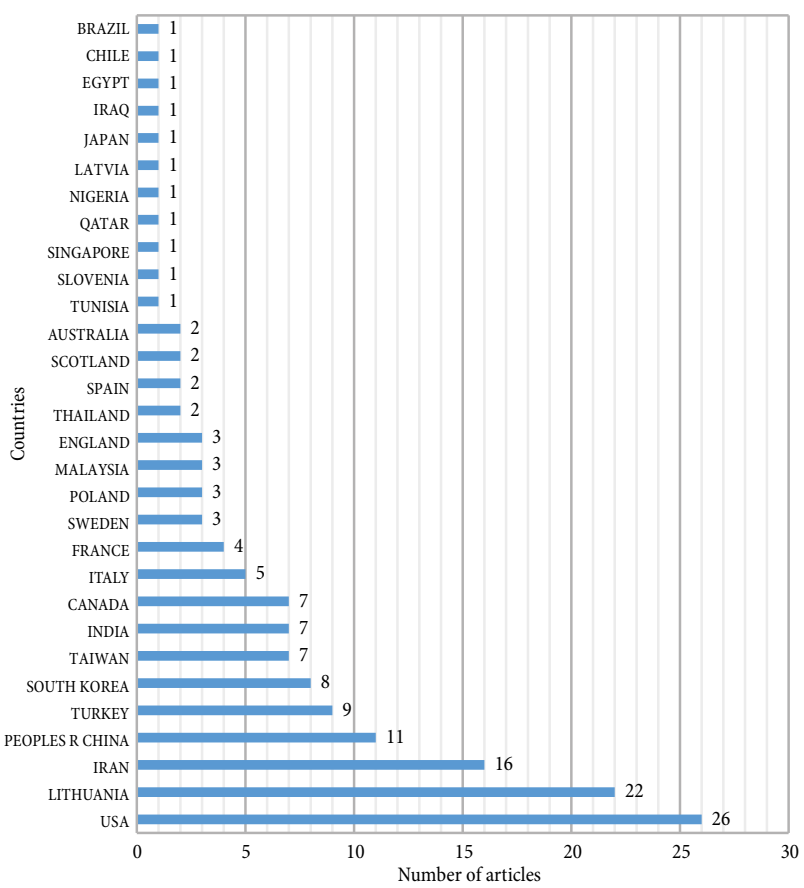

Fig. 6. MCDM application by country (number of publications) in the category of Civil Engineering

Table 2. Publications on the MCDM topic by author

\begin{tabular}{|l|c|}
\hline \multicolumn{1}{|c|}{ Author's name } & Articles \\
\hline Zavadskas EK & 15 \\
\hline Turskis Z & 11 \\
\hline Duckstein L & 6 \\
\hline Antucheviciene J & 5 \\
\hline Zahraie B & 4 \\
\hline Sadiq R & 4 \\
\hline Medineckiene M & 4 \\
\hline Li H & 4 \\
\hline Tesfamariam S & 3 \\
\hline Tamosaitiene J & 3 \\
\hline Susinskas S & 3 \\
\hline Raju KS & 3 \\
\hline Karamouz M & 3 \\
\hline Chung ES & 3 \\
\hline 21 authors & 2 \\
\hline 65 authors & 1 \\
\hline
\end{tabular}

with their journal Archives of Civil and Mechanical Engineering, which published seven articles on the topic.

Table 4 provides MCDM methods, their authors and numbers of publications, in which the methods were used. The table demonstrates that MADM methods AHP, SAW, TOPSIS, Permutation method, the 
Fuzzy Sets Theory (developed in 1965), and ELECTRE method that emerged in 1968 were mostly used in the period since 1980 (Hwang, Yoon 1981). Later decision making methods have been intensively developed and applied to various engineering and managerial problems. It should be noted that methods created by VGTU researchers are popular as well as used for addressing Civil Engineering issues.

Table 3. Publications on the MCDM topic by journal

\begin{tabular}{|c|c|}
\hline Sources titles & Articles \\
\hline Water Resources Management & 18 \\
\hline Journal of Civil Engineering and Management & 17 \\
\hline Archives of Civil and Mechanical Engineering & 7 \\
\hline Water Resources Bulletin & 5 \\
\hline $\begin{array}{l}\text { Stochastic Environmental Research and Risk } \\
\text { Assessment }\end{array}$ & 5 \\
\hline Energy and Buildings & 4 \\
\hline Automation in Construction & 4 \\
\hline Transportation & 3 \\
\hline Journal of Hydroinformatics & 3 \\
\hline Journal of Advanced Transportation & 3 \\
\hline Building and Environment & 3 \\
\hline Tunnelling and Underground Space Technology & 2 \\
\hline Transportation Research Record & 2 \\
\hline $\begin{array}{l}\text { Transportation Research Part E Logistics and } \\
\text { Transportation Review }\end{array}$ & 2 \\
\hline Structure and Infrastructure Engineering & 2 \\
\hline $\begin{array}{l}\text { Journal of Water Resources Planning and } \\
\text { Management Asce }\end{array}$ & 2 \\
\hline $\begin{array}{l}\text { Journal of Construction Engineering and } \\
\text { Management }\end{array}$ & 2 \\
\hline Journal of Computing in Civil Engineering & 2 \\
\hline Civil Engineering and Environmental Systems & 2 \\
\hline Baltic Journal of Road and Bridge Engineering & 2 \\
\hline Other 23 journals ${ }^{\star}$ & 1 \\
\hline
\end{tabular}

Note: ${ }^{\star}$ The following journals have one article each: Water International, Thin Walled Structures, Stochastic Hydrology and Hydraulics, Proceedings of the Institution of Mechanical Engineers Part F Journal of Rail And Rapid Transit, Preservation of Roadway Structures and Pavements, Ocean Engineering, Natural and Anthropogenic Disasters Vulnerability Preparedness and Mitigation, KSCE Journal Of Civil Engineering, Journal of Water Supply Research and Technology Aqua, Journal of Urban Planning and Development ASCE, Journal of Transportation Engineering ASCE, Journal of Performance of Constructed Facilities, Journal of Irrigation and Drainage Engineering, Journal of Hazardous Materials, Journal of Earthquake Engineering, Journal of Construction Engineering and Management ASCE, International Journal of Concrete Structures and Materials, European Journal of Environmental and Civil Engineering, Earthquakes and Structures, Construction and Building Materials, Computers Structures, Computer Aided Civil and Infrastructure Engineering, Advances in Structural Engineering.
Table 4. Methods applied in articles on Civil Engineering

\begin{tabular}{|l|c|}
\hline Methods & Articles \\
\hline AHP, Saaty 1980 & 37 \\
\hline TOPSIS, Hwang, Yoon 1981 & 22 \\
\hline Fuzzy Sets, Zadeh 1965 & 14 \\
\hline ELECTRE, Roy 1968 & 13 \\
\hline ANP, Saaty 1996 & 8 \\
\hline PROMETHEE, Mareschal, Brans 1992 & 7 \\
\hline COPRAS, Zavadskas et al. 1994b & 7 \\
\hline WASPAS, Zavadskas et al. 2012 & 6 \\
\hline ARAS, Zavadskas, Turskis 2010 & 5 \\
\hline VIKOR, Opricovic 1998 & 5 \\
\hline SAW, MacCrimon 1968 & 4 \\
\hline Entropy, Shannon 1948 & 3 \\
\hline SWARA, Kersuliene et al. 2010 & 2 \\
\hline Permutation method, Paelinck 1976 & 2 \\
\hline TODIM, Gomes, Lima 1992 & 1 \\
\hline
\end{tabular}

\section{Conclusions}

MCDM methods have been developing since the 18th century. Starting with 1990, research related to these methods gained a new momentum.

Currently, Thomson Reuters Web of Science Core Collection refers 2463 publications on a topic of MCDM, 1749 of which are articles.

Publications applying MCDM in Civil Engineering (138) are in the tenth place. Nevertheless, $61 \%$ of the publications were announced in 2011-2015.

Most publications (26) were announced by researchers of the USA. The second place is occupied by Lithuanian researchers with 22 publications.

The top ten of researchers with most articles on the MCDM topic involve five authors from VGTU.

The majority of publications (18) were printed in the journal Water Resources Management. The second place with 17 articles is occupied by the Journal of Civil Engineering and Management published by VGTU and Taylor \& Francis.

About $18 \%$ of all published articles used MCDM methods authored by VGTU researchers, namely, COPRAS, WASPAS, ARAS and SWARA.

\section{References}

Antucheviciene, J.; Kala, Z.; Marzouk, M.; Vaidogas, E. R. 2015. Solving civil engineering problems by means of fuzzy and stochastic MCDM methods: current state and future research, Mathematical Problems in Engineering 2015: 1-16. http://dx.doi.org/10.1155/2015/362579 
Arrow, K. J. 1951. Social choice and individual values. New Haven / New York/London: J. Wiley/Chapman \& Hall.

Belton, V.; Stewart, T. J. 2002. Multiple criteria decision analysis: an integrated approach. Dordrecht: Kluwer Academic Publishers. 372 p. http://dx.doi.org/10.1007/978-1-4615-1495-4

Borda, J. C. de. 1784. Mémoire sur les élections au scrutin. Paris: Historie de l'Academie Royale des Sciences.

Bose, P.; Chakrabarti, R. 2003. Application of optimized multicriteria decision-making in an environmental impact assessment study, Civil Engineering and Environmental Systems 20(1): 31-48. http://dx.doi.org/10.1080/10286600302230

Bouyssou, D.; Marchant, T.; Pirlot, M.; Tsoukias, A.; Vincke, P. 2006. Evaluation and decision models with multiple criteria: Stepping stones for the analyst. New York: Springer. $459 \mathrm{p}$.

Brauers, W. K. 2004. Optimization methods for a stakeholder society, a revolution in economic thinking by multi-objective optimization. Boston / Dordredit / London: Kluwer Academic Publishers.

Cantor, G. 1874. Ein Beitrag zur Mannigfaltigkeitslehre, J Reine Angew. Math 84: 242-258.

Charnes, A.; Cooper, W. W.; Rhodes, E. 1978. Measuring the efficiency of decision making units, European Journal of $\mathrm{Op}$ erational Research 2: 429-444.

http://dx.doi.org/10.1016/0377-2217(78)90138-8

Chen, Z.; Li, H. 2006. Environmental management in construction: A quantitative approach. London and New York: Taylor \& Francis. 232 p. http://dx.doi.org/10.4324/9780203030363

Condorcet, N. Marquis de. 1785. Essay on the application of anal$y$ sis to the probability of majority decisions. Bibliotheque $\mathrm{Na}$ tional de France.

Dantzig, G. B. 1948. Linear programming, in Problems for the Numerical Analysis of the Future, Proceedings of the Symposium on Modern Calculating Machinery and Numerical Methods, UCLA, 29-31 July 1948, Los Angeles, CA.

Debreu, G. 1959. Theory of value: an axiomatic analysis of economic equilibrium. New Haven and London: Yale University Press.

Doumpos, M.; Grigoroudis, E. 2013. Multicriteria decision aid and artificial intelligence: links, theory and applications. Chichester: John Wiley and Sons. 368 p. http://dx.doi.org/10.1002/9781118522516

Duckstein, L.; Bobée, B.; Ashkar, F. 1991. A multiple criteria decision modeling approach to selection of estimation techniques for fitting extreme floods, Stochastic Hydrology and Hydraulics 5(3): 227-238. http://dx.doi.org/10.1007/bf01544059

Edgeworth, F. Y. 1881. Mathematical psychics: an essay on the application of mathematics to the moral sciences. London: Kegan Paul \& Co.

Edwards, W. 1954. The theory of decision making, Psychological Bulletin 41: 380-417. http://dx.doi.org/10.1037/h0053870

Ehrgott, M.; Figueira, R. J.; Greco, S. (Eds.). 2010. Trends in multiple criteria decision analysis, in International Series in Operations Research \& Management Science, Vol. 142. Springer US. $412 \mathrm{p}$. http://dx.doi.org/10.1007/978-1-4419-5904-1

Fiedler, K.; Peldschus, F.; Zavadskas, E. K. 1986. Methoden Bautechnologischen Entscheidung. Wiss. Berichte der Technische Hochschule Leipzig H. 17: 1-56.
Figueira, J.; Greco, S.; Ehrgott, M. (Eds.). 2005. Multiple criteria decision analysis: state of the art surveys, in International Series in Operations Research \& Management Science, Vol. 78. Boston: Springer. 1085 p. http://dx.doi.org/10.1007/b100605

Filip, F. G.; Suduc, A.-M.; Bîzoi, M. 2014. DSS in numbers, Technological and Economic Development of Economy 20(1): 154-164. http://dx.doi.org/10.3846/20294913.2014.890139

Fishburn, P. C. 1964. Decision and value theory. New York: Wiley \& Sons.

Fishburn, P. C. 1970. Utility theory for decision making. New York: Wiley \& Sons.

Franklin, B. 1772. Letter to Joseph Priestley. Reprinted in the Benjamin Franklin Sampler, 1956. New York: Fawcett.

Frisch, R. 1961. Numerical determination of a quadratic preference function for use in macroeconomic programming, Giornale degli Economisti e Annali di Economia 20: 3-43.

Gass, S.; Saaty, T. 1955. Parametric objective function (part2)-Generalization, Journal of the Operations Research Society of America 3(4): 395-401. http://dx.doi.org/10.1287/opre.3.4.395

Gomes, L. F. A. M.; Lima, M. M. P. P. 1992. TODIM: basics and application to multicriteria ranking of projects with environmental impacts, Foundations of Computing and Decision Sciences 16(4): 113-127.

Gay, L. F.; Sinha, S. K. 2013. Resilience of civil infrastructure systems: literature review for improved asset management, International Journal of Critical Infrastructures 9(4): 330350. http://dx.doi.org/10.1504/ijcis.2013.058172

Hanne, T. 2001. Intelligent strategies for meta Multiple criteria decision making. Boston: Kluwer.

Herrera-Viedma, E. 2015. Fuzzy sets and fuzzy logic in Multicriteria decision making. The 50th Anniversary of Prof. Lotfi Zadeh'S theory: introduction, Technological and Economic Development of Economy 21(5): 677-683. http://dx.doi.org/10.3846/20294913.2015.1084956

Hwang, C.-L.; Masud, A. S. M. 1979. Multiple objective decision making - methods and application. A state-of-the-art survey. Berlin: Springer.

Hwang, C. L.; Yoon, K. 1981. Multiple attributes decision making methods and applications. Berlin, Hedelberg: Springer.

Hwang, C. L.; Lin, M. J. 1987. Group decision making under multiple criteria: methods and applications. Berlin: SpringerVerlag.

Ishizaka, A. Nemery, P. 2013. Multi-criteria decision analysis: methods and software. Chichester: John Willey \& Sons, p. 296. http://dx.doi.org/10.1002/9781118644898

Jato-Espino, D.; Castillo-Lopez, E.; Rodriguez-Hernandez, J.; Canteras-Jordana, J. C. 2014. A review of application of multi-criteria decision making methods in construction, Automation in Construction 45: 151-162. http://dx.doi.org/10.1016/j.autcon.2014.05.013

Kabir, G.; Sadiq, R.; Tesfamariam, S. 2013. A review of multicriteria decision-making methods for infrastructure management, Structure and Infrastructure Engineering 10(9): 11761210. http://dx.doi.org/10.1080/15732479.2013.795978

Kahraman, C. (Ed.) 2008. Fuzzy multi-criteria decision making. Theory and applications with recent developments, in Springer Optimization and Its Applications, Vol. 16. Turkey: Springer, Science+Business Media, LLC. 591 p. http://dx.doi.org/10.1007/978-0-387-76813-7 
Kaklauskas, A.; Zavadskas, E. K. 2002. Internetine sprendimu parama [Web-based intelligent decision support]. Vilnius: Technika (in Lithuanian).

Kaklauskas, A.; Kaplinski, O.; Peldschus, F.; Zavadskas, E. K. 2005. Historie und Trends des Kolloquiums, 20 Jahre wissenschaftlicher Gedenken austausch, Podium, Sonderheft 11:3-9.

Kaklauskas, A.; Zavadskas, E. K. (Eds.). 2015. Multiple criteria analysis of the life cycle of the built environment: Monograph. Vilnius: Technika. $448 \mathrm{p}$.

Kaliszewski, I. 2010. Soft computing for complex multiple criteria decision making. Berlin: Springer. $172 \mathrm{p}$.

Kantorovich, L. 1939. Mathematical methods of organizing and planning production (in English 1960), in Management Science 6(4): 363-422.

Kapliński, O. 1997. Modelling of construction processes: a managerial approach. Warszawa: Komitet Inzynierii Ladowej i Wodnej PAN. 175 p.

Kapliński, O.; Zavadskas, E. K.; Peldschus, F.; Kaklauskas, A. 2004. Problems and envolving trends of construction colloquia on decision making and operational research, Foundations of Civil and Environmental Engineering 5: 83-90.

Kapliński, O. (Ed.). 2007. Metody i modele badań w inżynerii przedsięwzięć budowlanych [Methods and models of research in construction project engineering]. Polish Academy of Science (in Polish). 415 p.

Kapliński, O. 2008a. Planning instruments in construction management, Technological and Economic Development of Economy 14(4): 449-451.

http://dx.doi.org/10.3846/1392-8619.2008.14.449-451

Kapliński, O. 2008b. Development and usefulness of planning techniques and decision-making foundations on the example of construction enterprises in Poland, Technological and Economic Development of Economy 14(4): 492-502. http://dx.doi.org/10.3846/1392-8619.2008.14.492-502

Kaplinski, O. 2009a. Sapere Aude: Professor Edmundas Kazimieras Zavadskas, Inzinerine Ekonomika - Engineering Economics 5: 113-119.

Kapliński, O. 2009b. Professor Edmundas Kazimieras Zavadskas: the research achievements and transborder cooperation, Archives of Civil Engineering 53(3): 287-300.

Kapliński, O. 2010. Review of trans-border co-operation in construction management between Lithuania, Germany and Poland, Evolution of Science and Technology - Mokslo ir Technikos Raida 2(1): 5-18.

http://dx.doi.org/10.3846/est.2010.22

Kapliński, O.; Tamošaitienė, J. 2010. Game theory applications in construction engineering and management, Technological and Economic Development of Economy 16(2): 348-363. http://dx.doi.org/10.3846/tede.2010.22

Kaplinski, O.; Tupenaite, L. 2011. Review of the multiple criteria decision making methods, intelligent and biometric systems applied in modern construction economics, Transformations in Business \& Economics 10(1): 166-181.

Kaplinski, O.; Peldschus, F.; Tamosaitiene, J. 2014a. Professor Edmundas Kazimieras Zavadskas: his academic research, school of thought, and most eminent results of his work, Archives of Civil Engineering 60(2): 287-292.

http://dx.doi.org/10.2478/ace-2014-0019

Kaplinski, O.; Peldschus, F.; Tupènaitè, L. 2014b. Development of MCDM methods - in honour of Professor Edmundas
Kazimieras Zavadskas on the occasion of his 70th birthday, International Journal of Computers Communications \& Control 9(3): 305-312.

http://dx.doi.org/10.15837/ijccc.2014.3.1084

Kaplinski, O.; Paslawski, J.; Zavadskas, E. K.; Gajzler, M. (Eds.) 2015. Innovative solutions in Construction Engineering and Management. Flexible Approach, Procedia Engineering 122: $1-320$.

Kaplinski, O.; Tamošaitienè, J. 2015. Analysis of normalization methods influencing results: a review to honour Professor Friedel Peldschus on the occasion of his 75th birthday, Procedia Engineering 122: 2-10. http://dx.doi.org/10.1016/j.proeng.2015.10.001

Keeney, R.; Raiffa, H. 1976. Decisions with multiple objectives: preferences and value. New York: Tradeoffs, Wiley.

Keršuliene, V.; Zavadskas, E. K.; Turskis, Z. 2010. Selection of rational dispute resolution method by applying new stepwise weight assessment ratio analysis (SWARA), Journal of Business Economics and Management 11(2): 243-258. http://dx.doi.org/10.3846/jbem.2010.12

Khandekar, A. V.; Antuchevičienè, J.; Chakraborty, S. 2015. Small hydro-power plant project selection using fuzzy axiomatic design principles, Technological and Economic Development of Economy 21(5): 756-772. http://dx.doi.org/10.3846/20294913.2015.1056282

Köksalan, M.; Wallenius, J.; Zionts, S. 2011. Multiple Criteria Decision Making: from early history to the 21st century. Singapore: World Scientific. http://dx.doi.org/10.1142/9789814335591

Koo, D. H.; Ariaratnam, S. T.; Kavazanjian, E. 2009. Development of sustainability assessment model. Development of sustainability assessment model for underground infrastructure. VDM Verlag Dr. Müller. 184 p.

Koopmans, T. C. 1951. Analysis of production as an efficient combination of activities, in T. C. Koopmans (Ed.). Activity analysis of production and allocation. Heidelberg: PhysicaVerlag.

Liou, J. J. H. 2013. New concepts and trends of MCDM for tomorrow - in honor of professor Gwu-Hsiung Tzeng on the occasion of his 70th birthday, Technological and Economic Development of Economy 19(2): 367-375. http://dx.doi.org/10.3846/20294913.2013.811037

Liou, J. J. H.; Tzeng, G.-H. 2012. Comments on "Multiple Criteria Decision Making (MCDM) methods in economics: an overview", Technological and Economic Development of Economy 18(4): 672-695. http://dx.doi.org/10.3846/20294913.2012.753489

Luce, R. D.; Raiffa, H. 1957. Games and decisions: introduction and critical survey. New York: Wiley \& Sons.

MacCrimmon, K. R. 1968. Decision making among multipleattribute alternatives: a survey and consolidated approach. RAND Memorandum, RM-4823-ARPA.

Mardani, A.; Jusoh, A.; Zavadskas, E. K. 2015. Fuzzy multiple criteria decision-making techniques and applications - two decades review from 1994 to 2014, Expert Systems with Applications 42(8): 4126-4148. http://dx.doi.org/10.1016/j.eswa.2015.01.003

Mardani, A.; Jusoh, A.; Nor, K. M. D.; Zakwan, N.; Valipour, A. 2015a. Multiple criteria decision-making techniques and their applications - a review of the literature from 2000 to 
2014, Economic Research - Ekonomska Istrazivanja 28(1): 516-571. http://dx.doi.org/10.1080/1331677x.2015.1075139

Mardani, A.; Jusoh, A.; Zavadskas, E. K.; Cavallaro, F.; Khalifah, Z. 2015b. Sustainable and renewable energy: an overview of the application of Multiple Criteria Decision Making techniques and approaches, Sustainability 7(10): 1394713984. http://dx.doi.org/10.3390/su71013947

Mardani, A.; Jusoh, A.; Zavadskas, E. K.; Khalifah, Z.; Nor, K. M. D. 2015c. Application of multiple-criteria decision-making techniques and approaches to evaluating of service quality: a systematic review of the literature, Journal of Business Economics and Management 16(5): 1034-1068. http://dx.doi.org/10.3846/16111699.2015.1095233

Mareschal, B.; Brans, J. P. 1992. PROMETHEE V: MCDM problems with segmentation constrains. Brussels: Universite Libre de Brusells.

Masri, H. 2014. Quantitative economics as a scientific approach to the solution of problems of a complex nature - in honor of Professor Willem Karel M. Brauers on the occasion of his 90(th) birthday, Technological and Economic Development of Economy 20(3): 590-600.

http://dx.doi.org/10.3846/20294913.2014.966350

Miettinen, K. 2009. Nonlinear multiobjective optimization. Berlin: Springer. 320 p. http://dx.doi.org/10.1007/978-1-4615-5563-6

Nash, J. 1950a. Equilibrium points in n-person games, Proceedings of the National Academy of Sciences of the United States of America 36(1): 48-49.

Nash, J. 1950b. The bargaining problem, Econometrica 18(2): 155-162.

Opricovic, S. 1998. Multicriteria optimization of Civil Engineering systems. Belgrade: University of Belgrade.

Paelinck, J. H. P. 1976. Qualitative multiple criteria analysis: environmental protection and multiregional development, Papers of the Regional Science Association 36(1): 59-74. http://dx.doi.org/10.1007/bf01944375

Pareto, V. 1896-1897. Cours E-Economic. Rouge: Université de Lausanne.

Pareto, V. 1906. Manuale di economia politica. Milan: Societá Editrice Libraria.

Pareto, V. 1971. Manual of political economy. New York: Augustus M. Kelley Publishers.

Pedrycz, W.; Ekel, P.; Parreiras, R. 2010. Fuzzy multicriteria decision-making: models, methods and applications. Chischester: John Willey \& Sons. 360 p. http://dx.doi.org/10.1002/9780470974032

Peldschus, F. 1986. Zur Anwendung der Theorie der Spiele für Aufgaben der Bautechnologie: Dissertation B. Technischen Hochschule Leipzig. 119 p.

Peldschus, F. 1995. Fuzzy Methoden in Bauwesen. 5. DeutschLitauisch-Polnisches Kolloquium Planungs instrumente in Baubetriebswesen, Leipzig, Beiträge zu Lehre und Forschung Sondercheft der HTWK: 21-25.

Peldschus, F. 2013. The 14th Colloquium - 33 Years of Successful Scientific Cooperation, in The 14th German-Lithuanian Colloquium on Innovative Solutions in Construction Technology and Management, 32-38.

Peldschus, F.; Kapliński, O.; Zavadskas, E. K.; Kaklauskas, A. 2006. History and trends of the colloquiums, Technological and Economic Development of Economy 12(3): 227-235.
Peldschus, F.; Zavadskas, E. K. 1997. Matrix games in building technology and management. Vilnius: Technika (in Lithuanian).

Pourahmad, A.; Hosseini, A.; Banaitis, A.; Nasiri, H.; Banaitiené, N. \& Tzeng, G.-H. 2015. Combination of fuzzy-AHP and DEMATEL-ANP with GIS in a new hybrid MCDM model used for the selection of the best space for leisure in a blighted urban site, Technological and Economic Development of Economy 21(5): 773-796. http://dx.doi.org/10.3846/20294913.2015.1056279

Ramsey, F. P. 1931. Truth and probability in the foundations of mathematics and other logical essays. London: Routledge and Kegan, 156-198.

Razavi Hajiagha, S. H.; Amoozad Mahdiraji, H.; Hashemi, S. S.; Turskis, Z. 2015. Determining weights of fuzzy attributes for multi-attribute decision-making problems based on consensus of expert opinions, Technological and Economic Development of Economy 21(5): 738-755. http://dx.doi.org/10.3846/20294913.2015.1058301

Roy, B. 1968. La methode ELECTRE, Revue d'Informatique et. de Recherche Operationelle (RIRO) 8: 57-75.

Roy, B. 1996. Multicriteria methodology for decision aiding. Berlin, Heidelberg: Springer Science \& Business Media. 293 p. http://dx.doi.org/10.1007/978-1-4757-2500-1

Saaty, T. L. 1980. The analytic hierarchy process. New York: McGraw-Hill.

Saaty, T. L. 1996. Decision making with dependence and feedback. The analytic network process. Pitsburg: RWS Publications. $370 \mathrm{p}$.

Samuelson, P. A. 1938. A note on the pure theory of consumer's behaviour, Economica 5: 61-71. http://dx.doi.org/10.2307/2548836

Sen, A. 1970. Collective choice and social welfare. San Francisco: Holden Day.

Shafike, N. G.; Duckstein, L.; Maddock, T. 1992. Multicriterion analysis of groundwater contamination management, Water Resources Bulletin 28(1): 33-43. http://dx.doi.org/10.1111/j.1752-1688.1992.tb03152.x

Shannon, C. E. 1948. A mathematical theory of communication, The Bell System Technical Journal 27: 379-423; 623-656. http://dx.doi.org/10.1002/j.1538-7305.1948.tb01338.x

Simon, H. A. 1955. A behavioral model of rational choice, Quarterly Journal of Economics 69: 99-118. http://dx.doi.org/10.2307/1884852

Sobanjo, J. O.; Stukhart, G.; James, R. W. 1994. Evaluation of projects for rehabilitation of highway bridges, Journal of Structural Engineering-ASCE 120(1): 81-99. http://dx.doi.org/10.1061/(asce)0733-9445(1994)120:1(81)

Tamosaitiene, J.; Bartkiene, L.; Vilutiene, T. 2010. The new development trend of operational research in Civil Engineering and sustainable development as a result of collaboration between German-Lithuanian-Polish scientific triangle, Journal of Business Economics and Management 11(2): 316-340. http://dx.doi.org/10.3846/jbem.2010.16

Tamosaitiene, J.; Kapliński, O. 2013. Strategic Environmental Assessment (SEA) of socio-economic systems: a systematic review, Technological and Economic Development of Economy 19(4): 661-674. http://dx.doi.org/10.3846/20294913.2013.862882

The Association of European Operational Research Societies (Euro). 2015. Euro Working Group OR in Sustainable 
Development and Civil Engineering [online], [cited 15 November 2015]. Available from Internet: http://www.orsdce. vgtu.lt/?id=54427.33862

Triantaphyllou, E. 2010. Multi-criteria decision making methods: a comparative study. Dordrecht: Springer Science \& Business Media. http://dx.doi.org/10.1007/978-1-4757-3157-6

Turskis, Z.; Zavadskas, E. K.; Antucheviciene, J.; Kosareva, N. 2015. A hybrid model based on fuzzy AHP and fuzzy WASPAS for construction site selection, International Journal of Computers Communications \& Control 10(6): 873-888. http://dx.doi.org/10.15837/ijccc.2015.6.2078

Tzeng, G.-H.; Huang, J.-J. 2011. Multiple attribute decision making: methods and applications. Boca Raton: Chapman and Hall/CRC Press.

Von Neumann, J.; Morgenstern, O. 1944. Theory of games and economic behaviour. Princeton: Princeton University Press.

Wiecek, M. M.; Ehrgott, M.; Fadel, G.; Figueira, J. R. 2008. Multiple criteria decision making for engineering, Omega 36(3): 337-339. http://dx.doi.org/10.1016/j.omega.2006.10.001

Yager, R. R. 2015. Foreword. Special issue on fuzzy sets and applications (Celebration of the 50th anniversary of fuzzy sets), International Journal of Computers Communications \& Control 10(6): 771.

Zadeh, L. A. 1965. Fuzzy sets, Information and Control 8: 338353. http://dx.doi.org/10.1016/s0019-9958(65)90241-x

Zavadskas, E. K. 1987a. Multiattribute decision making in construction: Dr. Sc. Dissertation. Institute of Civil Engineering, Moscow (in Russian). 720 p.

Zavadskas, E. 1987b. Complex estimation and choice of resourcesaving decisions in construction. Vilnius: Mokslas (in Russian). $2010 \mathrm{p}$.

Zavadskas, E. K. 1991. System of estimation of technological solutions in building construction. Leningrad: Stroizdat (in Russian). $256 \mathrm{p}$.

Zavadskas, E.; Peldschus, F.; Kaklauskas, A. 1994a. Multiple criteria evaluation of projects in construction. Vilnius: Technika. $226 \mathrm{p}$.

Zavadskas, E. K.; Kaklauskas, A.; Sarka, V. 1994b. The new method of multicriteria complex proportional assessment of projects, Technological and Economic Development of Economy 1(3): 131-139.

Zavadskas, E.; Kapliński, O.; Kaklauskas, A.; Brzeziński, J. 1995. Expert systems in construction industry. Trends, potencial \& applications. Vilnius: Technika. $180 \mathrm{p}$.

Zavadskas, E. K.; Simanauskas, L.; Kaklauskas, A. 1998. Multiple criteria decision support systems. Vilnius: Technika (in Lithuanian).

Zavadskas, E. K. 2000. Mehrkriterielle Entscheidungen im Bauwesen. Vilnius: Technika.

Zavadskas, E. K.; Kaklauskas, A.; Banaitienè, N. 2001. Pastato gyvavimo proceso daugiakriterine analizé [Multiple criteria analysis of a building's life cycle]. Vilnius: Technika (in Lithuanian).

Zavadskas, E. K.; Ustinovichius, L.; Peldschus, F. 2003. Development of software for multiple criteria evaluation, Informatica 14(2): 259-272.
Zavadskas, E. K.; Peldschus, F.; Ustinovicus, L.; Turskis, Z. 2004a. Game theory in building technology and management. Vilnius: Technika (in Lithuanian).

Zavadskas, E. K.; Kaklauskas, A.; Banaitis, A.; Kvederyte, N. 2004b. Housing credit access model: the case for Lithuania, European Journal of Operational Research 155(2): 335-352. http://dx.doi.org/10.1016/S0377-2217(03)00091-2

Zavadskas, E. K.; Kaklauskas, A. 2007. Mehrzielselektion für Entscheidungen im Bauwesen. Stuttgart: IRB Verlag (in German). $276 \mathrm{p}$.

Zavadskas, E. K. 2008. History and evolving trends of construction colloquia on sustainability and operational research, Technological and Economic Development of Economy 14(4): 578592. http://dx.doi.org/10.3846/1392-8619.2008.14.578-592

Zavadskas, E. K.; Liias, R.; Turskis, Z. 2008. Multi-attribute decision-making methods for assessment of quality in bridges and road construction: state-of-the-art surveys, Baltic Journal of Road and Bridge Engineering 3(3): 152-160.

http://dx.doi.org/10.3846/1822-427X.2008.3.152-160

Zavadskas, E. K.; Turskis, Z. 2010. A new additive ratio assessment (ARAS) method in multicriteria decision-making, Technological and Economic Development of Economy 16(2): 159-172. http://dx.doi.org/10.3846/tede.2010.10

Zavadskas, E. K.; Turskis, Z. 2011. Multiple Criteria Decision Making (MCDM) methods in economics: an overview, Technological and Economic Development of Economy 17(2): 397-427. http://dx.doi.org/10.3846/20294913.2011.593291

Zavadskas, E. K.; Turskis, Z.; Antuchevičienè, J.; Zakarevičius, A. 2012. Optimization of weighted aggregated sum product assessment, Electronics and Electrical Engineering 122(6): 3-6. http://dx.doi.org/10.5755/j01.eee.122.6.1810

Zavadskas, E. K.; Turskis, Z.; Kildiene, S. 2014. State of art surveys of overviews on MCDM/MADM methods, Technological and Economic Development of Economy 20(1): 165-179. http://dx.doi.org/10.3846/20294913.2014.892037

Zavadskas, E. K.; Vilutienè, T. 2013. Operations research in areas of civil engineering and sustainable development: EURO working group activities, Organization, Technology \& Management in Construction: An International Journal 5(1): 650-653.

Zeleny, M. 1974. A concept of compromise solution and the method of displaced ideal, Computers and Operations Research 1(3): 479-496. http://dx.doi.org/10.1016/0305-0548(74)90064-1

Zeleny, M. 1975. MCDM - State and future of arts, Operations Research 23(Supplement 2): B413-B413.

Zeleny, M. 1982. Multiple criteria decision making. New York: McGraw-Hill.

Zionts, S. 1979. MCDM - If not a Roman Numeral, then what, Interfaces 9(4): 94-101. http://dx.doi.org/10.1287/inte.9.4.94

Zopounidis, C.; Pardalos, P. M. (Eds.). 2010. Handbook of multicriteria analysis. Berlin, Heidelberg: Springer-Verlag. http://dx.doi.org/10.1007/978-3-540-92828-7 
Edmundas Kazimieras ZAVADSKAS is Professor, Head of the Department of Construction Technology and Management at Vilnius Gediminas Technical University, Vilnius, Lithuania, and a chief researcher at Research Institute of Smart Building Technologies. He has a PhD in building structures (1973) and DrSc (1987) in building technology and management. He is a member of the Lithuanian and several foreign Academies of Sciences. He is Doctor Honoris Causa at Poznan, Saint-Petersburg, and Kiev universities. He is Editor in Chief and a member of editorial boards of a number of research journals. He is author and co-author of more than 400 papers and a number of monographs. Research interests are: building technology and management, decisionmaking theory, automation in design and decision support systems.

Oleg KAPLIŃSKI is Professor of Civil Engineering at Faculty of Architecture (IAP), Poznan University of Technology, Poznan, Poland. He lectures economics and organization of the investment process, as well as the theory and principles of work places design. The author of 240 publications. Doctor Honoris Causa of VGTU (1996). Member of the CE Committee of the Polish Academy of Sciences. His current research are: an integral management, integral design, risk management, theory of decision making and research methods in CE and architecture.

Jurgita ANTUCHEVIČIENE் is Professor at the Department of Construction Technology and Management at Vilnius Gediminas Technical University, Vilnius, Lithuania. She received a PhD in Civil Engineering in 2005. She is author and co-author of about 50 scientific papers. Research interests include: multiple criteria analysis, decision-making theories and decision support systems, sustainable development, construction management and investment. 